\title{
PRIVATISASI BADAN USAHA MILIK NEGARA
}

\author{
Freedom Abetnego Siahaan ${ }^{1}$, Sri Redjeki Hartono ${ }^{2}$
}

\begin{abstract}
ABSTRAK
BUMN merupakan pelaku ekonomi yang sangat vital perannya dalam Pembangunan Nasional. Peran BUMN yang sangat vital tersebut ternyata tidak diikuti dengan kinerja BUMN yang membaik justru sebaliknya, kinerja BUMN malah mengecewakan. Salah satu cara yang dapat ditempuh guna mengembangkan BUMN agar menjadi perusahaan yang kinerjanya baik, efisien, profesional dan transparan adalah melalui mekanisme privatisasi. Privatisasi BUMN merupakan salah satu bagian dari upaya pembenahan guna mendayagunakan dan mengembangkan BUMN sehingga BUMN dapat memberikan kontribusi yang maksimal kepada negara. Dalam pelaksanaan privatisasi hendaknya semua pihak yang terkait mampu untuk bekerja sama dan saling mendukung sehingga pelaksanaan program privatisasi dapat berjalan dengan efektif.
\end{abstract}

Kata Kunci: Privatisasi, BUMN.

\begin{abstract}
State Owned Enterprises (SOE's) is a vital economic actor in National Development. The vital role of SOE's in fact was not followed by the improvement of its performance, otherwise It was disappointing. One choice that can be taken in order to develop the SOE's to get better performance, efficient, professional and transparent is through privatization mechanism. Privatization of SOE's is an effort to empower and develop the SOE's so that It can give maximum contribution to the state. In the implementation of privatization, all the parties concerned should be able to work together and support each other so that privatization can run effectively.
\end{abstract}

Keywords: Privatization, State Owned Enterprise (SOE's)

1 Mahasiswa Program Studi Magister Ilmu Hukum UNDIP

2 Dosen Program Studi Magister IImu Hukum UNDIP 


\section{A. PENDAHULUAN}

\section{Latar Belakang}

Badan Usaha Milik Negara (BUMN) merupakan pelaku ekonomi yang didirikan oleh negara berdasarkan Pasal 33 ayat 2 Undang-Undang Dasar 1945 yang menyatakan "bahwa segala sesuatu yang menyangkut hajat hidup orang banyak harus dikuasai oleh negara" dan implementasi penguasaannya antara lain ditafsirkan dilakukan oleh pelaku ekonomi yaitu BUMN. Selain BUMN pelaku ekonomi lainnya adalah Swasta dan Koperasi. Dalam menjalankan kegiatan usahanya, BUMN, Swasta dan Koperasi melaksanakan peran saling mendukung berdasarkan demokrasi ekonomi.

BUMN pada awalnya dibentuk karena adanya keyakinan bahwa pemerintah mempunyai kemampuan untuk menghasilkan sendiri barang dan jasa serta mendistribusikannya di pasar. Kondisi ini mendorong intervensi pemerintah dalam operasional BUMN menjadi dominan. Inkonsistensi dan ketidakjelasan ini selanjutnya membawa dampak infleksibilitas operasional, lingkungan kerja yang pasif dan kurang kreatif, lebih patuh pada prosedur pemerintah daripada menjalankan norma berbisnis, transaksi biaya yang tinggi dan akhirnya terjadi inefisiensi BUMN yang didirikan oleh negara memiliki dua bentuk, yaitu Perusahaan Perseroan dan Perusahaan Umum. Pasal 1 angka (2) Undang-Undang BUMN menyebutkan bahwa Perusahaan Perseroan (Persero) adalah BUMN yang berbentuk perseroan terbatas yang modalnya terbagi dalam saham yang seluruh atau paling sedikit 51\% (lima puluh satu persen) sahamnya dimiliki oleh Negara Republik Indonesia yang tujuan utamanya mengejar keuntungan. Perusahaan Perseroan ini sepenuhnya tunduk pada ketentuan Undang-Undang Nomor 40 tahun 2007 tentang Perseroan Terbatas. Pengertian Perusahaan Umum (Perum) menurut Pasal 1 angka (4) adalah BUMN yang seluruh modalnya dimiliki negara dan tidak terbagi atas saham, yang bertujuan untuk kemanfaatan umum berupa penyediaan barang dan/atau jasa yang bermutu tinggi dan 
sekaligus mengejar keuntungan berdasarkan prinsip pengelolaan perusahaan. Dibentuknya Perusahaan Umum adalah sebagai implementasi kewajiban pemerintah guna menyediakan barang dan jasa tertentu untuk memenuhi kebutuhan masyarakat. Namun dari kedua bentuk BUMN tersebut diatas, yang dapat diprivatisasi hanyalah BUMN yang berbentuk Perseroan saja. Privatisasi merupakan simbol dari upaya mengurangi peranan negara dan memberi kepercayaan dan kesempatan kepada swasta dalam sistem perekonomian suatu negara untuk memenuhi kebutuhan masyarakat.

Privatisasi BUMN merupakan salah satu bagian dari upaya pembenahan guna mendayagunakan dan mengembangkan BUMN untuk dapat menjadi perusahaan yang efisien dan produktif dalam penyelenggaraan bidang usahanya. Konsep dasar dari privatisasi BUMN adalah terjadinya pengalihan kepemilikan dari negara kepada swasta. Dengan demikian, privatisasi BUMN diharapkan dapat meringankan beban pemerintah baik secara finansial maupun administratif dalam penyelenggaraan BUMN. ${ }^{3}$

\section{Metode Penelitian}

Penelitian yang berjudul "Privatisasi Badan Usaha Milik Negara" ini menggunakan metode pendekatan yuridis-normatif yang membutuhkan data akurat yang dititik beratkan pada data sekunder yang diperoleh dari penelitian kepustakaan. Data sekunder tersebut berupa bahan-bahan hukum primer, bahan hukum sekunder serta bahan hukum tersier.

\section{Kerangka Teori}

Badan usaha adalah perusahaan berbentuk badan hukum yang menjalankan jenis usaha bersifat tetap, terus-menerus dan didirikan sesuai dengan peraturan perundang-undangan yang berlaku serta bekerja dan berkedudukan dalam wilayah Negara Kesatuan Republik Indonesia. ${ }^{4}$

Berdasarkan Pasal 1 angka 1 Undang-Undang No.19 tahun 2003

\footnotetext{
3 Aminuddin Ilmar, 2004, Privatisasi BUMN di Indonesia, Makassar, Hasanuddin University Press, hlm 32.

4 Kamus ,2008, Kamus Hukum, Bandung, Citra Umbara, hlm 49.
} 
tentang Badan Usaha Milik Negara, yang dimaksud dengan Badan Usaha Milik Negara atau yang sering disingkat dengan BUMN, adalah badan usaha yang seluruh atau sebagian besar modalnya dimiliki oleh negara melalui penyertaan secara langsung yang berasal dari kekayaan negara yang dipisahkan. BUMN adalah suatu entitas privat yang tujuan utamanya adalah mengejar keuntungan berdasarkan prinsip pengelolaan perusahaan yang artinya adalah bahwa BUMN sebagai perusahaan dapat melakukan kegiatan-kegiatan yang lazim dilakukan oleh perusahaan pada umumnya.

Privatisasi menurut ketentuan Pasal 1 angka 12 Undang-Undang No.19 tahun 2003 tentang Badan Usaha Milik Negara adalah penjualan saham Persero, baik sebagian maupun seluruhnya, kepada pihak lain dalam rangka meningkatkan kinerja dan nilai perusahaan, memperbesar manfaat bagi negara dan masyarakat, serta memperluas pemilikan saham oleh masyarakat.

Privatisasi BUMN umumnya dimaksudkan sebagai salah satu upaya untuk memberdayakan BUMN baik dari segi manajemen, permodalan atau pembiayaan maupun pengurangan campur tangan negara serta memberi kesempatan kepada swasta untuk mengambil peran dalam kegiatan ekonomi. Melalui privatisasi BUMN diharapkan manajemen BUMN bebas dalam menentukan gerak perusahaan, menetapkan kebijakan investasi dan pendanaannya serta pemenuhan sumber daya manusianya. ${ }^{5}$

Pelepasan saham BUMN dapat dilakukan dengan berbagai cara, diantaranya yang sering digunakan adalah dengan cara Strategic Sales, Initial Public Offering (IPO) dan Private Placement. Ada 2 (dua) alasan mengapa pelepasan saham BUMN diperlukan: pertama, membebaskan intervensi politik dan kedua, untuk transparansi dan pengawasan masyarakat. Keterangan tersebut diatas memberikan gambaran bahwa politik dan bisnis mempunyai karakter dan tujuan yang berbeda, mencampuradukkan tujuan politik dan bisnis dalam fungsi BUMN akan

\footnotetext{
${ }^{5}$ Aminuddin Ilmar, Op Cit, hlm 37.
} 
mengorbankan kepentingan bisnis suatu BUMN. Organ pemerintah dapat mempergunakan BUMN sebagai alat untuk memenuhi kepentingan politiknya atau melaksanakan program instansi induknya, sementara pegawai BUMN dapat berlindung dibalik tirai fungsi sosial dan tugas pemerintah atas suatu kegagalan BUMN.

Pilihan privatisasi diharapkan menjadi solusi yang efektif terhadap masalah in-efisiensi BUMN. Melalui mekanisme privatisasi, mayoritas saham dialihkan kepada pihak swasta. Dengan demikian, campur tangan birokrasi diputuskan dan kelemahan mendasar (inefisiensi) BUMN dapat segera diatasi. Karena itu, manajemen BUMN mesti sepenuhnya ditangani oleh kalangan swasta yang memang memiliki kamampuan yang profesional untuk mengelola BUMN. Dalam konteks inilah privatisasi dimaksudkan sebagai upaya peningkatan kegiatan penyebaran kepemilikan perusahaan mengakses pendanaan, teknologi, manajemen modern dan pasar internasional. ${ }^{6}$

Dalam melaksanakan kebijakan privatisasi BUMN tidak lepas dari dasar hukum yang mengaturnya. Dasar hukum bagi pelaksanaan privatisasi BUMN antara lain Undang-Undang Dasar 1945, Undang-Undang No.19 tahun 2003 tentang Badan Usaha Milik Negara, dan Peraturan Pemerintah No.59 tahun 2009 tentang Perubahan Atas Peraturan Pemerintah No.33 tahun 2005 tentang Tata Cara Privatisasi Perusahaan Perseroan. Dasar hukum bagi privatisasi tersebut haruslah konsisten, jika tidak maka proses privatisasi akan mengalami kendala baik internal maupun eksternal. Agar program privatisasi berjalan dengan baik, diperlukan payung hukum dan peraturan yang jelas, sehingga semua pihak yang terlibat dapat memahami dengan baik.

B. HASIL PENELITIAN DAN PEMBAHASAN

1. Latar Belakang dan Tujuan Dilakukannya Kebijakan

\footnotetext{
6 Azwir Dainy Tara, 2003, Menggugah BUMN Membangun Ekonomi Rakyat, Jakarta, Nuansa Madani, hlm 75.
} 
Privatisasi BUMN Di Indonesia

Privatisasi terhadap BUMN yang ada di Indonesia sekarang ini dianggap menjadi suatu hal yang sangat vital guna pengembangan BUMN. Pelaksanaan privatisasi terhadap BUMN diharapkan membuat BUMN menjadi lebih sehat dan berdaya saing. Privatisasi BUMN dilakukan tentunya bukan tanpa sebab, ada hal-hal yang melatarbelakangi pelaksanaan privatisasi BUMN di Indonesia, hal-hal tersebut antara lain:

a. Inefisiensi yang terjadi pada BUMN

$$
\text { Inefisiensi merupakan }
$$
masalah yang paling umum dalam BUMN. Inefisiensi ini dikarenakan BUMN dalam menjalankan kegiatan bisnisnya diberikan keistimewaan oleh pemerintah berupa proteksi, monopoli, dan subsidi sementara kinerja BUMN tidak membaik dan kualitas produk yang dihasilkan juga kurang bagus dengan harga yang tinggi.

Keistimewaan-keistimewaa $\mathrm{n}$ tersebut diatas menyebabkan BUMN menjadi sangat nyaman bergantung pada pemerintah, BUMN tidak berupaya untuk mandiri dan bekerja secara efisien untuk meningkatkan kinerja perusahaan. Hal ini menyebabkan BUMN semakin kesulitan untuk berkompetisi dengan pihak swasta yang memanfaatkan aset yang dimilikinya dengan sebaik-baiknya. Tingginya biaya yang dikeluarkan BUMN untuk menghasilkan produk barang/jasa tidak dibarengi dengan kualitas yang baik, sehingga produk yang dihasilkan BUMN kalah dari produk yang dihasilkan pihak swasta.

b. Pengelolaan BUMN yang tidak profesional dan transparan

BUMN selaku pelaku
ekonomi nasional yang sangat
diandalkan untuk meningkatkan
pertumbuhan ekonomi nasional
sudah selayaknya dikelola secara
profesional dan transparan.
Namun seringkali yang terjadi
malah sebaliknya, pengelolaan
BUMN dilakukan secara tidak
profesional dalam bidangnya serta


tidak tranparan. Hal ini

pengambilan keputusan

disebabkan dari kuatnya pengaruh

politik dalam tubuh BUMN.

Transparansi dalam BUMN penting guna menjaga agar BUMN dijalankan secara profesional. Dengan adanya tranparansi maka masyarakat atau pihak lain juga dapat mengetahui perkembangan yang terjadi dalam BUMN, masyarakat sebagai pihak yang juga berkepentingan akan kesehatan dan peningkatan kinerja BUMN dalam hal ini juga dapat menjadi pengawas akan kegiatan yang dilakukan BUMN sehingga BUMN tetap terkontrol dan diharapkan semakin meningkatkan kinerjanya.

c. Integrasi vertikal yang berlebihan pada BUMN

Pengelola BUMN sering terhambat dalam melaksanakan kebijakan perusahaan dikarenakan seringnya kebijakan pemerintah sangat intervensif sehingga manajemen BUMN sering mengalami hambatan dalam

d. Praktik-praktik ilegal dan korupsi

di tubuh BUMN dikarenakan kesalahan para profesional pengelolanya, tetapi juga dikarenakan struktur organisasi dan keberadaannya yang tidak menguntungkan. BUMN berada dibawah departemen teknis sehingga otomatis ada kecenderungan dari para pengelola BUMN untuk menjaga hubungan ekstra baik dengan pimpinan departemen teknisnya daripada konsumennya. Hal ini tidak aneh karena pada akhirnya penentuan siapa yang berhak menduduki posisi puncak dalam BUMN tidak lebih ditentukan oleh prestasi bisnis atau konsumennya, melainkan lebih pada pimpinan departemen teknis yang membawahinya. 
Tingginya praktik-praktik ilegal dalam tubuh BUMN juga menjadi salah satu hal yang melatarbelakangi diprivatisasinya BUMN. Salah satu contohnya ialah pernyataan Menteri Negara BUMN Dahlan Iskan yang menyatakan bahwa BUMN yang bergerak dalam bidang konstruksi rawan terlibat kasus korupsi. ${ }^{7}$ Praktik ilegal seperti suap, pengadaan barang dan jasa yang tidak sesuai prosedur, korupsi, kolusi, dan nepotisme, serta beberapa praktik ilegal lain dalam pengelolaan BUMN menunjukkan banyaknya pihak yang ingin mendapatkan keuntungan dari BUMN. Praktik-praktik ilegal ini menyebabkan BUMN tidak bekerja dengan semestinya dan sulit untuk bekerja secara profesional guna pengembangan BUMN.

\footnotetext{
Sebagai suatu perusahaan sangat tidak baik jika jalannya perusahaan harus dicampuri dengan tujuan-tujuan yang bukan merupakan tujuan bisnis. Hal ini akan

${ }^{7}$ Kompas.com, Dahlan: Kontraktor BUMN Paling Rawan Korupsi, 4 Juni 2012.
}

menyebabkan terganggunya proses peningkatan efisiensi yang merupakan suatu hal yang harus dilakukan suatu perusahaan yang ingin berkembang. Orang banyak yang mengatakan slogan" kegiatan bisnis bukanlah kegiatan sosial". Hal ini tentu ada maksudnya, tak lain adalah jika tujuan bisnis perusahaan dicampuri dengan tujuan sosial maka akan berdampak buruk pada kinerja perusahaan yang tujuan utamanya adalah mendapatkan keuntungan, dalam hal ini BUMN. Oleh karena itu perlu kiranya agar pelaksanaan kegiatan usaha BUMN tidak dicampuri dengan tujuan yang bukan tujuan bisnis.

Pelaksanaan privatisasi BUMN juga didasarkan pada tujuan tertentu yang ingin dicapai, tujuan tersebut yaitu untuk meningkatkan kinerja dan nilai tambah perusahaan dan meningkatkan peran serta masyarakat dalam pemilikan saham Persero dengan memperhatikan prinsip-prinsip transparansi, kemandirian, akuntabilitas, pertanggungjawaban dan kewajaran.

2. Pelaksanaan Privatisasi BUMN Di Indonesia 
Pelaksanaan privatisasi BUMN

di Indonesia sudah dimulai pada awal tahun 1980, yang merupakan bagian dari sistem pembinaan BUMN yang diarahkan untuk mewujudkan good corporate governance. Sedangkan istilah BUMN baru dikenal sejak diterbitkannya PP No.3/1983 tentang Tata Cara Pembinaan dan Pengawasan Perusahaan Jawatan (Perjan), Perusahaan Umum (Perum), dan Perusahaan Persero (Persero).

Pada pelaksanaan privatisasi BUMN, bukan berarti kendali negara atas BUMN yang bersangkutan menjadi berkurang atau hilang karena negara tetap menjalankan fungsi penguasaan melalui regulasi sektoral tempat BUMN yang di privatisasi melaksanakan kegiatan usahanya.

Pedoman bagi pelaksanaan
privatisasi BUMN di Indonesia
sebagai 4 pelaksana
Undang-Undang No.19 tahun 2003
yaitu Peraturan Pemerintah No.33
tahun 2005 tentang Tata Cara
Privatisasi Perusahaan Persero dan
Peraturan Pemerintah No.59 tahun
2009 tentang Perubahan Atas
Peraturan Pemerintah No.33 tahun

2005. Dalam melaksanakan program privatisasi, pemerintah tidak dapat bertindak sendiri. Perusahaan yang telah diseleksi dan memenuhi kriteria yang telah ditentukan perlu dikonsultasikan terlebih dahulu kepada DPR-RI sesuai dengan ketentuan pasal 82 UU No.19 tahun 2003 yang berbunyi:

(1) Privatisasi harus didahului dengan tindakan seleksi atas perusahaan-perusahaan dan mendasarkan pada kriteria yang ditetapkan dalam peraturan pemerintah,

(2) Terhadap perusahaan yang telah diseleksi dan memenuhi kriteria yang telah ditentukan, setelah mendapat rekomendasi dari Menteri Keuangan, selanjutnya disosialisasikan kepada masyarakat serta dikonsultasikan kepada Dewan Perwakilan Rakyat.

Hal ini sangat perlu dilakukan untuk mengurangi resistensi dari masyarakat luas karena DPR-RI merupakan representasi masyarakat Indonesia. Konsultasi kepada 
DPR-RI dilakukan dengan harapan pelaksanaan privatisasi dapat berjalan dengan lancar.

Persero yang dapat di privatisasi sekurang-kurangnya harus memenuhi kriteria sebagai industri/sektor usaha yang kompetitif atau industri/sektor usaha yang unsur teknologinya cepat berubah. Sebaliknya, persero yang tidak dapat diprivatisasi adalah persero yang bidang usahanya berdasarkan pada peraturan perundang-undangan hanya boleh dikelola oleh BUMN, persero yang bergerak di sektor usaha yang berkaitan dengan pertahanan dan keamanan negara, persero yang bergerak di sektor tertentu yang oleh pemerintah diberi tugas khusus melaksanakan kegiatan tertentu yang berkaitan dengan kepentingan masyarakat, dan persero yang bergerak di bidang usaha sumber daya alam.

Peraturan Pemerintah No.33 tahun 2005 dan Peraturan Pemerintah No.59 tahun 2009, keduanya hanya mengatur privatisasi Persero, sepanjang dimungkinkan berdasarkan peraturan perundang-undangan di sektor tempat persero yang bersangkutan melakukan kegiatan usahanya. Sebaliknya, Perusahaan Umum (Perum), menurut UU No.19 tahun 2003 tentang BUMN tidak dimungkinkan untuk di privatisasi. Persero dapat di privatisasi karena selain dimungkinkan oleh ketentuan di bidang Pasar Modal juga karena pada umumnya telah bergerak dalam sektor-sektor yang kompetitif dan pelaksanaan privatisasi harus senantiasa memperhatikan manfaat bagi kepentingan rakyat.

Pemerintah dapat melakukan program privatisasi di negara Indonesia setelah DPR-RI memberikan persetujuan atas RAPBN yang di dalamnya terdapat target penerimaan negara dari hasil privatisasi. Rencana privatisasi sebagaimana dimaksud dituangkan dalam program tahunan privatisasi yang pelaksanaannya dikonsultasikan kepada DPR-RI.

Pada saat pengusulan RAPBN kepada DPR-RI, pemerintah menyertakan daftar BUMN yang akan di privatisasi dalam tahun anggaran yang bersangkutan untuk memenuhi target penerimaan negara dari hasil privatisasi yang 
direncanakan dalam RAPBN tersebut. Dengan demikian, persetujuan yang diberikan oleh DPR-RI atas RAPBN yang dimaksud sudah termasuk didalamnya persetujuan atas rencana privatisasi BUMN yang akan dilaksanakan oleh pemerintah sebagaimana dimaksud dalam Pasal 24 UU No.17 tahun 2003 tentang Keuangan Negara. Rencana privatisasi yang telah disetujui DPR-RI tersebut selanjutnya dituangkan dalam program tahunan privatisasi sebagaimana dimaksud dalam Pasal 12 PP No.33 tahun 2005.

Privatisasi dilakukan berdasarkan prinsip-prinsip transparansi, kemandirian akuntabilitas, pertanggungjawaban, kewajaran, dan prinsip harga terbaik dengan memperhatikan kondisi pasar. Dalam hal ini kondisi pasar yang dimaksud adalah kondisi pasar Domestik dan Internasional.

Pelaksanaan privatisasi di Indonesia berdasarkan Pasal 78 Undang-Undang No.19 tahun 2003 tentang BUMN hanya dimungkinkan dengan tiga macam metode saja, yaitu: a. Penjualan saham berdasarkan ketentuan pasar modal (Initial Public Offering)

b. Penjualan saham langsung kepada investor ( Strategic Sales )

c. Penjualan saham kepada manajemen dan/atau karyawan yang bersangkutan (Employee and/or Management Buy Out)

Setelah dilakukannya privatisasi diharapkan akan terjadi perubahan atas budaya perusahaan sebagai akibat dari masuknya pemegang saham baru, baik melalui penawaran umum (go public) ataupun melalui penyertaan langsung (direct placement). Perusahaan akan dihadapkan pada kewajiban pemenuhan persyaratan-persyaratan keterbukaan (disclosure) yang merupakan persyaratan utama dari suatu proses go public, atau adanya sasaran-sasaran perusahaan yang harus dicapai sebagai akibat masuknya pemegang saham baru. Budaya perusahaan yang berubah tersebut akan dapat mendorong peningkatan kinerja perusahaan yang selanjutnya akan dapat mempertinggi daya saing perusahaan dalam 
berkompetisi

dengan

pesaing-pesaing, baik nasional,

regional, bahkan global sehingga

pada akhirnya akan dapat

memberikan kontribusi yang lebih

besar terhadap perekonomian

nasional dalam bentuk barang dan jasa yang semakin berkualitas dan terjangkau harganya, serta penerimaan negara dalam bentuk pajak yang akan semakin besar pula.

3. Kendala-Kendala Yang Dihadapi dan Cara Mengatasi Kendala Dalam Pelaksanaan Privatisasi BUMN DI Indonesia

\section{Pelaksanaan kegiatan}

privatisasi tersebut tidaklah mudah, terdapat beberapa kendala baik yang bersifat yuridis maupun non yuridis yang dihadapi yang menyebabkan terhambatnya pelaksanaan privatisasi tersebut. Kendala-kendala tersebut menyebabkan pelaksanaan program privatisasi menjadi tidak lancar dan bahkan program privatisasi tersebut tidak mencapai tujuan.
Kendala yang bersifat Yuridis yaitu penegakan hukum yang sulit dalam pelaksanaan privatisasi. Kendala ini terutama terjadi bila privatisasi dilaksanakan dengan cara penjualan saham berdasarkan ketentuan pasar modal. Hal ini dikarenakan hingga sekarang perkembangan pasar modal masih mempunyai sektor yuridis yang lemah, cukup banyak lubang yang dapat dimanfaatkan untuk tujuan yang destruktif oleh siapa saja dari para pelaku pasar modal tersebut. Tindakan tersebut dapat berupa rekayasa, lips service, insider trading, pengelabuan, kongkalikong dan sebagainya yang sebagian besar tidak dapat terdeteksi secara jelas. ${ }^{8}$ Selain itu, pelaksanaan privatisasi BUMN juga dapat dilakukan dengan cara yang tidak fair. Hal ini dapat terlihat dari banyaknya kasus-kasus legal yang tidak dapat segera dipecahkan oleh penegak hukum Indonesia terhadap pelaku ekonomi pada pasar modal Indonesia. Pelanggaran terbesar berturut-turut adalah kasus-kasus yang berkaitan

\footnotetext{
8 Jurnal:Pandu Patriadi, Segi Hukum Bisnis Dalam Kebijakan Privatisasi BUMN Melalui Penjualan Saham Di Pasar Modal Indonesia, Kajian Ekonomi dan Keuangan, Maret 2004, hal 69.
} 
dengan keterbukaan informasi, benturan kepentingan, perdagangan saham, insider trading, dan manipulasi pasar. ${ }^{9}$

Kendala privatisasi yang Non Yuridis yaitu pengaruh politik dalam pelaksanaan privatisasi. Pelaksanaan privatisasi juga tidak luput dari aktivitas politik yang ada. Hingga saat ini banyak kekuatan politik yang ingin mengontrol dan menjadikan BUMN sebagai "sapi perahan". Belum lagi terdapat banyak sekali kepentingan yang ada dalam tubuh BUMN yang saling tarik-menarik antara elit politik dengan manajemen BUMN. Politisi menjadikan BUMN sebagai wadah untuk memberikan reward bagi loyalis dan sebaliknya pihak manajemen BUMN memberikan "upeti" karena telah memperoleh posisi yang baik di BUMN yang bersangkutan. Istilah Upeti ini sejalan dengan pernyataan Menteri Negara BUMN Dahlan Iskan di Televisi yang mengatakan bahwa BUMN telah menjadi sapi perahan Anggota DPR yang menginginkan

9 Pandu Patriadi, Ibid, hal 71. upeti dari para petinggi $\mathrm{BUMN}^{10}$.

Hal ini semakin menunjukkan bagaimana tokoh politik memiliki peran yang sangat besar dalam terlaksananya program kebijakan privatisasi yang sudah direncanakan. Niat tokoh politik untuk menjadikan BUMN sebagai sapi perahan tentunya menyebabkan terganggunya pelaksanaan privatisasi BUMN tersebut. Misalnya, dengan lamanya proses persetujuan Program Tahunan Privatisasi oleh DPR dapat menyebabkan program privatisasi yang sudah direncanakan kehilangan momentum pelaksanaan privatisasi. Hal ini juga bisa disebabkan karena tidak dominannya partai pemerintah di DPR, akibatnya persetujuan Program Tahunan Privatisasi sering terlambat dan privatisasi BUMN menjadi kehilangan momentum.

Kendala berikutnya adalah perbedaan persepsi diantara stakeholder dan juga masyarakat. Tidak dapat dipungkiri meskipun para stakeholder dalam suatu BUMN sama-sama menginginkan kemajuan

\footnotetext{
10 Suara Anda,"Dahlan Iskan \& Sapi Perah DPR'Metro TV pukul 19.00 WIB, tgl 26-12-2012.
} 
untuk suatu BUMN, namun mereka dapat memiliki persepsi yang berbeda mengenai cara yang akan ditempuh untuk mencapai tujuan yang mereka tetapkan. Hal ini adalah suatu yang wajar, karena tidak semua pihak memiliki persepsi yang sama akan suatu hal. Suatu hal yang baik menurut pandangan seseorang belum tentu baik menurut pandangan orang lain, begitu juga para stakeholder dalam BUMN, beberapa mungkin setuju privatisasi dilakukan untuk membenahi BUMN namun pihak yang lain kurang setuju dan berpendapat dengan cara yang bukan privatisasi lebih baik dalam membenahi BUMN. Begitu pula halnya masyarakat yang sering berbeda pandangan mengenai privatisasi yang dianggap hanya sebagai penjualan aset negara semata. Hal ini sering menjadi hambatan jika tidak ditindaklanjuti dengan baik.

Kultur dalam BUMN itu sendiri juga dapat menjadi kendala yang menyebabkan pelaksanaan privatisasi menjadi terhambat. Hampir di semua lini dan level dalam BUMN, mulai dari tingkat Menteri hingga jajaran Direksi berperilaku sebagai pemegang saham, di samping fungsi-fungsi lain yang dimiliki pemerintah sebagai regulator. Akibatnya setiap keputusan selalu melalui proses yang panjang dan memakan waktu lama. Ini berbeda dengan kultur di swasta, dimana operasionalisasi perusahaan pada umumnya langsung ditangani oleh pihak manajemen tanpa selalu menghadapi intervensi langsung dari pemegang saham. Jika dilihat dari perspektif waktu, maka proses go public swasta cuma memerlukan waktu beberapa bulan sedangkan BUMN membutuhkan waktu lebih dari satu tahun.

$$
\text { Kendala-kendala diatas }
$$
apabila terus dibiarkan tentu akan menghambat proses pelaksanaan kegiatan privatisasi BUMN kedepannya, beberapa cara atau solusi yang dapat dilakukan untuk mengatasi kendala tersebut yaitu:

a. Untuk kendala yang bersifat yuridis yaitu penegakan hukum yang sulit dalam pelaksanaan privatisasi BUMN dapat diatasi dengan cara mempersiapkan pengaturan hukum yang lebih lengkap dan jelas baik Undang-Undang maupun 
peraturan-peraturan pendukung

lainnya sebelum kebijakan

privatisasi dilaksanakan. Dengan

demikian para penegak hukum

mempunyai kekuatan yang lebih

kuat dalam menegakkan hukum

dalam pelaksanaan privatisasi.

Penegakan hukum yang baik

tentunya akan menciptakan

pelaksanaan privatisasi yang fair

dan mencapai tujuan serta

memberikan manfaat yang

sebesar-besarnya untuk negara dan

BUMN itu sendiri..

b. Untuk kendala-kendala yang bersifat Non Yuridis dapat ditempuh dengan cara:

1) Menerapkan prinsip tata kelola perusahaan yang baik (Good Corporate Governance)

Penerapan prinsip tata kelola perusahaan yang baik (Good Corporate Goverannce) bukan saja hanya tugas Direksi BUMN, melainkan juga pemegang sahamnya yang dalam hal ini adalah Pemerintah. Dalam penerapan prinsip ini perlu kesediaan dari pengelola BUMN yaitu
Komisaris dan Direksi BUMN untuk melaksanakan tata kelola perusahaan yang berarti meletakkan manajemen profesional sebagai tata cara pengelolaan usaha, selain itu perlu juga kesediaan dari pemerintah untuk melaksanakan tata kelola perusahaan yang baik kepada BUMN. Hal ini karena salah satu bias tata kelola perusahaan adalah terlalu kuatnya campur tangan pemilik dalam perusahaan sehingga membuat perusahaan itu sendiri tidak mampu mengembangkan tata kelola perusahaan yang baik. Pemerintah bukan saja Presiden dan Kabinet, namun juga Parlemen DPR. Bagi pemerintah sebagai pemegang saham, dibutuhkan kesediaan untuk meletakkan BUMN sebagai sebuah lembaga bisnis yang mandiri dan dikelola sebagaimana sebuah bisnis, dan bukan sebagai bagian dari organisasi publik/politik atau bagian kekuasaan. Selama itu masih belum tercapai, maka pelaksanaan tata kelola 
perusahaan pada BUMN pasti mengalami kendala yang besar, dan berarti juga kendala bagi pemulihan ekonomi secara keseluruhan karena BUMN akan menjadi bagian dari kepentingan kekuasaan daripada kepentingan rakyat, baik rakyat sebagai konsumen maupun rakyat sebagai pemilik.

2) Sosialisasi secara kontinu mengenai konsep dasar privatisasi

Agar program privatisasi dapat berjalan dengan mulus dan minim hambatan maka sosialisasi secara kontinu tentang konsep dasar privatisasi adalah salah satu langkah yang dapat ditempuh. Pemerintah perlu menyusun program kampanye nasional secara konseptual dan terencana. Dengan demikian bukan hanya stakeholder saja tetapi juga seluruh lapisan masyarakat benar-benar memahami dan menyadari peran strategis dari kebijakan privatisasi BUMN.

Masyarakat dan para stakeholder harus bisa menangkap esensi dari program privatisasi BUMN. Sama juga halnya bahwa pemerintah harus membuat pilihan terhadap pola privatisasi secara terencana dan dengan pertimbangan yang matang, sehingga dapat mendatangkan hasil yang maksimal.

\section{DAFTAR PUSTAKA}

Dainy Tara, Azwir, 2003, Menggugah BUMN Membangun Ekonomi Rakyat, Jakarta, Nuansa Madani.

Ilmar, Aminuddin, 2004, Privatisasi BUMN di Indonesia, Makassar, Hasanuddin University Press.

Iskan, Dahlan, Dahlan: Kontraktor BUMN Paling Rawan Korupsi, Kompas.com, 4 Juni 2012.

Kamus, 2008, Kamus Hukum, Bandung, Citra Umbara.

Patriadi, Pandu, 2004, Segi Hukum Bisnis Dalam Kebijakan Privatisasi BUMN Melalui Penjualan

Saham Di Pasar Modal Indonesia, Jurnal: Kajian Ekonomi dan 
Keuangan.

Undang-Undang Dasar Republik

Indonesia tahun 1945.

Undang-Undang No.19 Tahun 2003

tentang Badan Usaha Milik Negara.

Peraturan Pemerintah No.33 tahun

2005 tentang Tata Cara Privatisasi

Perusahaan Perseroan.

Peraturan Pemerintah No.59 tahun

2009 tentang Perubahan Atas

Peraturan Pemerintah No.33 Tahun

2005 tentang Tata Cara Privatisasi

Perusahaan Perseroan. 